\title{
The Third-Party Funding in Arbitration: A Challenge in Times of Crisis
}

\author{
Maria João Mimoso \\ Portucalense University \\ Joana Lourenço Pinto \\ Portucalense University
}

\section{Abstract}

Arbitration as a way of resolving disputes between companies is essentially linked to the advantages of arbitration, especially with the speed and neutrality of arbitration, as well as the confidentiality, the possibility of choosing arbitrators with precise technical knowledge in the area of litigation, among others. The parties choose arbitration as a means of resolving disputes, relating to interests of an equity nature, bearing in mind that for some legislators the emphasis is on the availability of rights, arising from the contractual relationship that unites them. The payment of costs is a sine qua non condition for the constitution of the arbitral tribunal. The parties must proceed with the payment of taxes and fees, respectively to the arbitration center they have chosen and the arbitrators they have chosen. Considering that the economic situation of the companies may fluctuate, either during the execution of the main contract, or when the dispute arises, the constitution of the arbitral tribunal and during the procedural iter, the possibility of financing the arbitration was outlined. Third-Party Funding is a figure that involves a third-party, unrelated to the litigation, who will defray the expenses due by one of the parties to the arbitration. It will have as a counterpart the participation in the eventual financial result achieved through the success of the arbitration. As a methodology, in addition to analyzing the state of the art, we will indicate real cases and the reasons for the growth of this instrument, without forgetting the ethical issues involved.

Keywords: arbitration, companies, disputes, ethic, financing 


\section{Introduction}

\section{What is funded arbitration}

Defining what is the "third-party funding", hereinafter referred to as TPF, is not an easy or peaceful task, due to the simple fact that there is no consensus regarding this figure, besides its scarce regulation.

What makes it difficult to define it is precisely the existence of a series of modalities for financing litigation by third parties.

TPF, in the most common modality, can be defined as a form of financing, whether partial or total, in which a third-party, through a contract, undertakes to finance the costs necessary and inherent to the litigation, both judicial and arbitration, of a litigant. In return, the disputing party must reimburse and / or remunerate the thirdparty (TPF) with the gains it may receive with the conclusion of the dispute (LegalToday, 2018).

Even though this is the most common modality, the truth is that there is no consensual understanding as to the characterization and definition of TPF.

The difficulty felt by several authors and researchers in the construction of a solid and unique definition is notorious.

Even among those who defend a broad definition of TPF, there are voices around a more economical conception and that indicate that it can contemplate several figures, and the remuneration of the third-party must always be directly linked to the litigation gains. On the other hand, some argue that it is not possible to obtain a definition based on a single conception, since there are several types of financing (Goldsmith, et al., 2010), (Gonçalves, 2018).

All these controversies make the TFP delimitation task an almost impossible mission. There were even those who believed that we could embark on undefinition. However, if that were the case, we would fall into great instability, especially for those who bet on the TPF market.

The lack of definition of the TPF would increase the discomfort in the use of this instrument, whether regarding legal aspects or even economic ones. This is undoubtedly the reason why there are several attempts at conceptualization, which are different, and which we can find, expressly or implicitly, in some of the instruments that provide for and regulate the TPF.

In this context, the IBA Guidelines on Conflict of Interest (of the International Bar Association) is of great importance, constituting a crucial instrument in assisting arbitration proceedings. They are an instrument of soft law, being the first regulatory rules of the TPF in commercial arbitration and foreign investment (Hodges, 2017). 
Not defining TPF concretely, the truth is that they determine what should be understood by TPF. This may be any entity that contributes funds or any material support to one of the parties to the arbitration procedure and that has a direct economic interest in the decision that will result in the arbitration (General Standard 6 (b) of the IBA Guidelines), (Gonçalves, 2018).

The IBA Guidelines also establish an important distinction between TPF and insurance denominated as ATE and BTE insurances. These are legal expenses insurance and are generally called BTE (before the event) or ATE (after the event) insurance, depending on when the respective policy is signed.

Regarding ATE, it is important to contract insurance by one of the parties to cover the risk of paying legal fees due to the other party. However, the formalization of this contract comes after the event that originated the dispute and, in turn, the respective judicial / arbitration procedure.

As for BTE, and unlike the first ones, they are contracted before the occurrence of any event and include not only the payment of the costs that the dispute involves to the hiring party, as well as the payment of costs to the counterparty, if that is the gist of the decision (Justice Jackson, 2009).

We can then see that, in the TPF, there is a direct economic interest in the litigation, and that, contrary to the stated insurance, ATE and BTE, there is a duty of compensation arising from the contract.

Within the scope of the various attempts to define and regulate the TPF, the Hong Kong Law Reform Commission followed a different path and ended up updating the legislation on Arbitration and Mediation. More recently, in 2017, TPF was legally defined as a financing agreement, by a third-party, to one of the litigating parties, with it having a benefit as a counterpart. This depends on the competent action being deemed valid and within the stipulated in the respective agreement.

In the Report of the ICCA-Queen Mary Task Force on Third-Party Funding in International Arbitration, published in 2018, TPF is expected to receive a remuneration or refund of the investment it has made, depending on the partial or total success of the dispute resolution, and alternatively, it may depend on the payment of a premium.

It is, in fact, fundamental to reach a general definition of the figure, so that an effective regulation can be outlined, implementing legal certainty and security.

However, we consider that there are at least three characteristics that must be present in the TPF: the funder must have no connection with the litigation; the purpose of the financing is intended to meet the costs arising from a dispute; the financier must be reimbursed for the amount disbursed, plus a remuneration, agreed in the contract, depending on the success or result of the dispute. 


\section{The TPF delimitation}

The TPF is a solution that allows access to justice for all litigants or, to put it more concretely, that allows all parties, who do not have sufficient financial resources, to face a litigation, whether judicial or arbitration.

If the importance of this figure was already dazzled, today, in the middle of the Covid19 era, the TPF assumes a unique relevance. The difficulties experienced by companies and commerce in general, in an unprecedented struggle and with a considerable decrease in their profits and even in assets, will provide a fertile ground for the means of out-of-court dispute resolution, maxime arbitration.

The slight delimitation of the figure, as referred, feeds a panoply of TPF modalities. One focuses on the possibility for a particular company to sell its shares or issue bonds, to obtain capital and thus finance litigation. Another arises with the so-called special-purpose vehicles (SPV), in which the SPV becomes the holder of the right of action, being this (SPV) held by an entity originally holder of that right. The TPF, in turn, acquires shares in SPV and, therefore, will itself finance the judicial or arbitration process (Report of the ICCA-Queen Mary, 2018). In this way, the financier will have greater control over the ongoing processes, since he becomes a shareholder of the company that is a party to the lawsuit, allowing for possible reimbursement and remuneration, certainly in the form of dividends.

We cannot forget that the markets are constantly developing, especially the capital market, developing various forms of financing. In this context, the portfolio funding emerged. This mechanism allows several cases to be financed in a single act through a simplified process and under the terms agreed between the financier and the financed. Portfolio funding offers all the benefits of financing a single case along with the additional benefits of financing at scale, diversifying financial risk and allowing for planning.

This mechanism proves to be one of the most attractive modalities for the parties in conflict, not only because the financier, when investing, has a lower associated risk, as well as it allows the financed party to manage its liquidity, since it will not support the total of the costs inherent to a process, or will not bear it at all, whether judicial or arbitration.

To clarify the problem, pay attention to the Tenor Capital case and the financing granted to the company "Crystallex".

"The Canadian company Crystallex had been expropriated from its mining unit in the Bolivarian Republic of Venezuela, and for that reason, initiated arbitration with the International Centre for the Settlement of Investment Disputes (commonly referred to as "investment arbitration" or "ICSID arbitration"). Subsequently, Crystallex sought to obtain financing through the issuance of USD 120 million debt securities, which were intended for payment to creditors and to meet the costs of the investment arbitration 
process. Having been unsuccessful in this operation, the company filed for insolvency and asked the Canadian court to grant authorization to obtain alternative financing, for both purposes indicated. It was then authorized to carry out a financing operation that involved the injection of capital into the company aimed at paying creditors, developing the company's operations, and promoting investment arbitration. In this financing, the financing entity ("Tenor Capital"), in addition to obtaining several guarantees for the payment of its credits, also appointed two of the five members of the supervised company's board of directors. The particularity of this financing resides in the fact that a portion of the financing is liquidated in terms like the financing obtained in the financial markets (capital and interest liquidation) and the other is subject to the pure "third-party funding" regime, that is, it is subject to the risk associated with the outcome of the process." (Henriques, n/a).

As we have seen, there are several financing models that are provided by the market dynamics and by the needs that are being imposed by the respective economic agents. In view of the market's globalization and the intensification of trade, it will be easy to understand the exponential growth of transnational disputes.

We also verified the scarce information on the exact number of funders or brokers, which shows some reluctance by these subjects / entities to assume this position, precisely due to the lack of regulation and, mainly, due to the lack of definition of the TPF figure.

There are several problems, so we will return to this topic later, just stating, at this moment, that a litigation financier is a financial investor. In this sense, the right to "a portion of the future product" of the litigation is acquired. However, such activity involves risk. For this reason, economically attractive lawsuits with a reasonable expectation of success will be part of the financing agreement.

In this context, international arbitrations are chosen by investors / financiers, given their high amounts and greater predictability of results. In addition to specific needs (eg cash flow), companies seek this type of financing to reach a partner with whom to share the action's risk. It is a special partner, as it only seeks the profitability of the "business", without interfering, from the outset, in the legal strategy of the action. This will certainly be desirable goal. But, as we will see, there will be a need to guard against future conflicts of interest.

\section{Disclosure of financing agreements}

We will now inquire whether the party that resorted to the financing will be required to report this fact to the arbitral tribunal and whether, at the same time, it should disclose the terms of the financing to the counterparty.

On the one hand, we cannot forget that, in general, the state laws on arbitration and the regulations of the institutions that administer arbitrations contain rules on the independence and impartiality of arbitrators. On the other hand, the financing of 
arbitration is equated, with due caution, to the legal aid provided by States to the neediest who wish to access justice. In the context of arbitration, financing by a thirdparty will undoubtedly go to international trade operators.

As law is shaped by social reality, the need to regulate the TPF was felt from the beginning, seeking to implement good practices.

The first guidelines on conflicts of interest in international arbitration (2014) are due to (IBA) as mentioned. Now, it is important to attend to some of them. See, especially, General Principle 6 (b), where it is stated that:

"If one of the parties is a legal entity, any legal or physical person having a controlling influence on the legal entity, or a direct economic interest in, or a duty to indemnify a party for, the award to be rendered in the arbitration, may be considered to bear the identity of such party.

The explanatory note to this guideline clarifies that" (...) General Standard 6 (b) clarifies that such legal persons and individuals may be considered effectively to be that party. Third-party funders and insurers in relation to the dispute may have a direct economic interest in the award, and as such may be considered to be the equivalent of the party. For these purposes, the terms 'third-party funder' and 'insurer' refer to any person or entity that is contributing funds, or other material support, 15 to the prosecution or defense of the case and that has a direct economic interest in, or a duty to indemnify a party for, the award to be rendered in the arbitration".

General Principle 7 (a) also protects the third funder, providing that "A party shall inform an arbitrator, the Arbitral Tribunal, the other parties and the arbitration institution or other appointing authority (if any) of any relationship, direct or indirect, between the arbitrator and the party (or another company of the same group of companies, or an individual having a controlling influence on the party in the arbitration), or between the arbitrator and any person or entity with a direct economic interest in, or a duty to indemnify a party for, the award to be rendered in the arbitration. The party shall do so on its own initiative at the earliest opportunity".

They clarify, in the respective annotation, that: "The parties are required to disclose any relationship with the arbitrator. Disclosure of such relationships should reduce the risk of an unmeritorious challenge of an arbitrator's impartiality or independence based on information learned after the appointment. The parties' duty of disclosure of any relationship, direct or indirect, between the arbitrator and the party (or another company of the same group of companies, or an individual having a controlling influence on the party in the arbitration) has been extended to relationships with persons or entities having a direct economic interest in the award to be rendered in the arbitration, such as an entity providing funding for the arbitration, or having a duty to indemnify a party for the award". 
The need to communicate the existence of financing to the Arbitral Tribunal is evident. In fact, the IBA 2014 Guidelines state, right in the introduction, that, with the emergence of large economic groups and international law firms, the development of international trade leads to situations of possible conflicts of interest and, therefore, should be revealed in arbitration. Thus, the third financier is equated to a party.

This issue is directly related to the arbitrator's independence and impartiality, which is, in fact, included in any law or regulation on arbitration, although these terms must be understood, as they cover different realities. Independence refers to the personal relationship that is established between the party and the referee and is determined in a more objective way, while impartiality is more abstract and linked to the referee's state of mind (Hong-Lin \& Shore, 2003).

It is important to bear in mind that, on the one hand, global advocacy, business standards, increasingly complex corporate structures, the obscurity of relationships, which are increasingly intricate, and, on the other hand, the different cultural environments where arbitration takes place, access to indirect information facilitated by telecommunications, have all provided an exponential increase in questions about the behaviour of referees (Imsdahl, 2011).

Attempting to prevent "less ethical" behaviours, the IBA 2014 Guidelines also provide a list of colours in view of the severity of the circumstance that affects the impartiality or independence of the referee. We reiterate that these attributes constitute a fundamental rule of the procedure. This means that the arbiter not only has a duty to be impartial and independent but must also needs to be this way in the eyes of others. This duty includes the need to disclose any circumstance that may jeopardize confidence in the impartiality of judging.

Offensive behaviour regarding these duties could amount to a serious violation of the fundamental procedural rule and, therefore, be reflected materially in the decision (cf. International Centre for Settlement of Investment Disputes Washington, DC In the proceedings between Suez, Sociedad General de Aguas de Barcelona SA, and Vivendi Universal SA (Claimants) and The Argentine Republic (Respondent) ICSID. Case. No. ARB / 03/19), (Júdice \& Calado, 2016).

Under this arbitration, the Arbitral Tribunal established parameters regarding the impartiality of the arbitrators. He stressed the need to analyse the relationship between the party and the appointed arbitrator, their proximity and intensity of the relationship, as well as the referee's material dependence on said relationship.

These parameters have been followed by several Arbitral Tribunals and must also be applied whenever a relationship with a third-party financier is at stake (Goeler, 2016). The Arbitral Tribunal should therefore inquire whether the TPF is directly involved in the appointment of the arbitrator. 
We have no doubts in stating that the TPF poses entirely new questions and facts for arbitration. Imagine the following situation: In a given arbitration, $\mathrm{F}$ is the plaintiff's TPF and X, the arbitrator appointed by the plaintiff. In another arbitration, with another plaintiff, now B, the designated arbitrator X, now becomes B's lawyer, and the TPF of this arbitration is the same F. Even more: X may have friends, family or colleagues who work for $\mathrm{F}$, or worse, $\mathrm{X}$ is himself a shareholder of $\mathrm{F}$. As can be seen from the examples above, $\mathrm{F}$ and $\mathrm{X}$ inevitably have a close relationship, so $\mathrm{X}$ cannot prevent suspicions about the part financed by $\mathrm{F}$ (Phan, $\mathrm{n} / \mathrm{d}$ ).

Disclosure of the funder's identity and the purpose of the financing agreement at the beginning of the process is vital to avoid procedural challenges during the procedural iter or subsequent attacks on the enforceability of the judgment; Article V (1) (d) of the 1958 New York Convention on the recognition and enforcement of foreign arbitration awards.

Disclosure of financing is also justified in relation to the allocation of the costs of arbitration. At the time of granting the arbitral award, the Arbitral Tribunal may determine the reimbursement of the advance amount by the winning party and the losing party may not be able to afford the expenses.

In view of the above, the financed party must notify the Arbitral Tribunal of the existence of a possible financing agreement. Only in this way, will the Tribunal be in a position to demand or not appropriate bond, in order to minimize the risk of a future breach of the counterparty's obligation to repay. It should be noted that the losing party may have been the party financed in the arbitration process (Scherer, 2013).

As mentioned, another question arises: the disclosure of the content of the financing agreement. Let us not forget the role of the TPF and its interest in arbitration.

The counterparty, which has no financing, may want to inquire about the interests that move the financier. In short, the financing conditions.

However, this matter is not peaceful at all in the doctrine, since the disclosure of this information can jeopardize the duty of confidentiality, as well as the financiers' market itself (Teixeira, 2016).

It is natural for the funder to want to know in detail about the dispute, in order to be able to measure and decide whether to make the financing agreement. It becomes reasonable and even understandable that the financier receives information during the arbitration procedure, either as a way of monitoring the possible return on his investment, or to understand expenses incurred during the arbitration (Freitas, 2015).

The IBA 2014 Guidelines will once again be, without a doubt, an excellent instrument to assess this triangle of relations, party, financier, and arbitrator. 


\section{Some Contributions to TPF transparency}

The Report of the ICCA-Queen Mary Task Force on third-party funding in international arbitration, April 2018, as mentioned above, is an important instrument for the parties, arbitrators and TPF, seeking to expedite the problems that arise during a financed arbitration. Its authors note that the report will not be the last word on TPF but will constitute a working basis for the future.

They list a number of Principles on disclosure and potential conflicts of interest with arbitrators. In accordance with the Principles and best practices, the following should be highlighted:

A party and/or its representative must, on its own initiative, disclose to the arbitrators and to the arbitration institution or nominating authority (if any) the existence of a third-party financing agreement and the identity of the funder.

The arbitrators and arbitration institutions are entitled to expressly request that the parties and their representatives disclose whether they are being financed and, if so, the identity of the financier.

According to the information provided, the existence of a potential conflict of interest between arbitrator and TPF must be assessed.

The Report also provides, in the guidelines it establishes, the Principles Regarding Privilege and Professional Secrecy and the Principles Regarding Costs and Security for Costs.

In short, the working group in question was concerned with the procedures, ethics and political issues related to the TPF in international arbitration, giving special importance to the regulation of the TPF in the harmonized context of the arbitration and integrity of the respective procedures.

Also, some jurisdictions have already introduced the TPF figure in their regulations within the arbitration framework. See the case of the rules of the Hong Kong International Arbitration Centre (HKIAC), referred to above, and the Singapore International Arbitration Centre (SIAC), which recently changed their legislation, establishing the legal framework for the use of TPF in arbitration.

Regarding Hong Kong, in short, the following discipline stands out: the activity of financing by a third-party of arbitration will exclude the direct or indirect participation of financiers who are integrated by lawyers or legal service providers, in order to avoid any conflict of interest; the communication of confidential information to a third-party or a potential third-party financier will be permitted and any recipient will be subject to confidentiality requirements; and the possibility of disclosing the existence of any third-party financing agreement to other parties, in order to avoid conflicts of interest in accordance with certain requirements. 
In turn, Singapore has legalized third-party financing not only for arbitrations, but also for legal proceedings, given that the legal text makes no distinction in this regard, referring only to procedures for resolving disputes. They imposed restrictions on the financing hypotheses, limiting them to international arbitrations; lawsuits arising from or related to international arbitrations; mediations, arising from or related to international arbitrations; specific execution actions of arbitration commitment. To this end, they determine that the financing must be carried out exclusively by a qualified financier imposing certain requirements.

A note, also, on the Arbitration Regulation of the International Chamber of Commerce (CCI) which, since the beginning of 2021, contains a set of new rules that seek to increase the flexibility, efficiency and transparency of the arbitrations administered by that institution.

In terms of guarantees of independence and impartiality of the arbitrators, the CCI Regulation prescribes the duty of the parties to inform about the existence and identity of third-parties with whom they have entered into agreements for financing the arbitration process - TPF - and who have, to that extent, an interest in the outcome of the arbitration (Article 11/7); the duty of the parties to inform about any change in their representatives and the power of the arbitral tribunal to take the measures they deem necessary to avoid conflicts of interest of any of the arbitrators as a result of this change (Article 17/1 and 2).

\section{Conclusions}

The lack of specific TPF regulation contributes and will definitely contribute to a certain distrust in the figure.

Most of the rules governing litigation financing are mere codes of conduct or good practices, and are intended, above all, to guard against conflicts of interest.

Consequently, there is a unity of voices around the "necessary obligation" that the financed party has to disclose all relevant information, avoiding a potential conflict of interest between the parties involved in the process, whether arbitration or judicial.

In order to assess the arbitrator's impartiality and independence as well as relationship with the TPF, the following aspects should be considered: the latter's control over the process, his influence on the appointment of the arbitrator, the frequency of the arbitrator's appointments and his fees (Koh, 2017).

Currently, given the effects of the Pandemic on the economy, an increase in litigation is expected, even though it seeks to respect, on the one hand, the force majeure clause and, on the other, the non-compliance, temporary or permanent, of the contractual obligations that the parties assumed in the international commercial contracts. 
Companies, as operators of international trade, will certainly be compelled to resort to litigation financing, so the TPF may present itself as a solution both in the scope of business mediation and, especially, in the context of international arbitration.

In fact, TPF has the capacity to transform a demand into a financial asset, which becomes, this way, the guarantor of a loan. This value will allow access to justice and facilitate, in terms of treasury, the possibility for companies to pay the respective costs and other arbitration expenses. However, this figure must be regulated, as it is extremely important that the entities that administer arbitrations, prevent possible conflicts of interest, adopting rules regarding the parties' duty to disclose the financing agreements and the identity of the TPF.

\section{References}

[1] Cremades, B. M. (2011). Third-party funding in international arbitration.

[2] Publicaciones de B. Cremades y Asociados. Available at: https://www.cremades.com/es/publicaciones/third-party-funding-ininternational-arbitration/

[3] Freitas, P. A. C. (2015). 0 financiamento de arbitragens por terceiros como garantia de acesso à Justiça. Migalhas. Available at: https://migalhas.uol.com.br/depeso/228459/o-financiamento-dearbitragens-por-terceiros-como-garantia-de-acesso-a-justica

[4] Goeler, J. V. (2016). Third-Party Funding in International Arbitration and its Impact on Procedure. Wolters Kluwer.

[5] Goldsmith, A.; Fléchet, C. \& Scherer, M. (2012). Third-party Funding in International Arbitration in Europe Part 1 - Funder's Perspectives, RDAI/IBLJ Roundtable.

[6] Gonçalves, A. M. (2018). Third-party Funding na Arbitragem Comercial, Master's thesis, NOVA University Lisbon.

[7] Henriques, D. G. (n/d). Third-party Funding ou o financiamento de litígios por terceiros em Portugal. Available at: https://www.josemigueljudicearbitration.com/xms/files/02_TEXTOS_ARBITRAGEM/19_Financiamento_Ar bitragem/Gorjao_Henriques_-_Financiamento_de_litigios_em_Portugal.pdf

[8] Hodges, P. (2017). Equality of Arms in International Arbitration: Who Is the Best Arbiter of Fairness in the Conduct of Proceedings? International Arbitration and the Rule of Law: Contribution and Conformity. Kluwer Law International. Netherlands.

[9] Hong-Lin, Y., \& Shore, L. (2003). Independence, Impartiality, and Immunity of Arbitrators-us and English Perspectives. International and Comparative Law Quarterly, 52(4), 935-967. doi:10.1093/iclq/52.4.935.

[10] ICC Arbitration Commission Report on Techniques for Controlling Time and Costs in Arbitration. Available at: https://iccwbo.org/publication/icc- 
arbitration-commission-report-on-techniques-for-controlling-time-andcosts-in-arbitration/

[11] Imsdahl. T. G. (2011). Quo Vadis? A Shifting Standard of Impartiality and Independence. International Institute for Conflit Prevention \& Resolution. . Available at: https://www.cpradr.org/news-publications/articles/2011-0505-quo-vadis-a-shifting-standard-of-impartiality-and-independence-2011writing-contest-winner

[12] International Centre for Settlement of Investment Disputes Washington, D.C. In the proceedings between Suez, Sociedad General de Aguas de Barcelona S.A., and Vivendi Universal S.A. (Claimants) and The Argentine Republic (Respondent) ICSID. Case No. ARB/03/19). Available at: https://www.italaw.com/sites/default/files/case-documents/ita0826.pdf

[13] Júdice, J.M. Calado, D. (2016). A independência e imparcialidade do árbitro: alguns aspetos polémicos, em uma visão luso-brasileira. Revista Brasileira de Arbitragem, no 49, Ano XIII. Wolters Kluver. Available at: https://a.storyblok.com/f/46533/x/b4a6487a4b/independencia-eimparcialidade-dos-arbitros-revista-brasileira-de-arbitragem-jose-migueljudice-diogo-calado-2016.pdf

[14] Justice Jackson, (2009). Review of Civil Litigation Costs: Final Report, 2009, pp 66-145. Available at: https://www.judiciary.uk/wpcontent/uploads/JCO/Documents/Reports/jackson-final-report-140110.pdf

[15] Koh, W. S. W. 2017). Think Quality Not Quantity: Repeat Appointments and Arbitrator Challenges, 34, Journal of International Arbitration, Issue 4, pp. 711-740. Available at:

[16] https://kluwerlawonline.com/journalarticle/Journal+of+International+Arbi tration/34.4/JOIA2017033

[17] Mattli, W.; Dietz, T. (2014). International Arbitration and Global Governance - Contending theories and evidence, Oxford University Press.

[18] Phan, A. N. (n/d). Mandatory Disclosure of Third-Party Funding in International Investment Arbitration: The EU-Vietnam Investment Protection Agreement as a Case Analysis. Available at:

https://www.academia.edu/38958295/Mandatory_Disclosure_of_Third_Par ty_Funding_in_International_Investment_Arbitration_The_EU_Vietnam_Inves tment_Protection_Agreement_as_a_Case_Analysis

[19] Queen Mary University of London, School of International Arbitration, (2015). International Arbitration Survey: Improvements and Innovations in International Arbitration. Available at:

http://www.arbitration.qmul.ac.uk/media/arbitration/docs/2015_Internati onal_Arbitration_Survey.pdf

[20] Report of the ICCA-Queen Mary task force on third-party funding in international arbitration, (2018). The ICCA Reports no. 4. Available at: 
https://cdn.arbitration-icca.org/s3fs-

public/document/media_document/Third-Party-Funding-Report\%20.pdf

[21] Scherer, M. (2013). Third-party funding in international arbitration.

Towards mandatory disclosure of funding agreements? Dossier of the ICC Institute of World Business Law: Third-party Funding in International Arbitration. Paris: International Chamber of Commerce.

[22] Teixeira, B. B. A. (2016). O Financiamento da Arbitragem por Terceiros e o Dever de Revelação. Comitê Brasileiro de Arbitragem. Avaiable at: http://www.cbar.org.br/blog/artigos/o-financiamento-da-arbitragem-porterceiros-e-o-dever-de-revelacao

[23] Yu, H., \& Shore, L. (2003). Independence, Impartiality, and Immunity of Arbitrators: US and English Perspectives. The International and Comparative Law Quarterly, 52(4), 935-967. Available at: http://www.jstor.org/stable/3663379 